\title{
PLANT AND SEED COLOURS IN CAÑÁHUA, CHENOPODIUM PALLIDICAULE
}

\author{
N. W. SIMMONDS \\ John Innes Institute, Hertford*
}

Received 10.x.65

\section{INTRODUCTION}

CAÑÁHUA ( $2 n=2 x=18$ ) is a minor grain crop of the high Andes of Bolivia and Peru (review of its economic botany in Simmonds, 1965). A stock collected at La Paz, Bolivia, by the writer in 1963 was used for the studies reported here. Cañáhua grows well in the summer in England, in the glasshouse or field, and large numbers of plants can be crowded into a small space: for example Ioo plants can be grown to fruiting in a box of size $14 \times 9$ inches. The flowers are hermaphrodite and extremely

TABLE

Segregations in Cañahua, Chenopodium pallidicaule

\begin{tabular}{|c|c|c|}
\hline & Observed & $\chi^{2}, \mathrm{P}$ \\
\hline $\begin{array}{l}\text { I. Red/green plant colour } \\
\text { Ratio } R r: R R \text { in } \mathrm{F}_{2} \\
\text { (progeny tests) } \\
\text { Ratio } R: r r \text { in } \mathrm{F}_{2}\end{array}$ & $\begin{array}{c}101 R r: 63 R R \\
2775 R: 1014 r r\end{array}$ & $\begin{array}{l}*\left\{\begin{array}{l}\text { dev. }[1]=1 \cdot 91,10-20 \text { per cent. } \\
\text { het. }[8]=15 \cdot 30,5-10 \text { per cent. }\end{array}\right. \\
\text { dev. }[1]=6 \cdot 27, \text { I- } 2 \text { per cent. } \\
\text { het. }[19]=17 \cdot 93,5^{0-70} \text { per cent. }\end{array}$ \\
\hline $\begin{array}{l}\text { 2. Black/brown seed colour } \\
\text { Ratio } B b: B B \text { in } \mathrm{F}_{2} \\
\text { (progeny tests) } \\
\text { Ratio } B: b b \text { in } \mathrm{F}_{2}\end{array}$ & $\begin{array}{l}17 B b: 12 B B \\
804 B: 251 b b\end{array}$ & $\begin{array}{l}\text { dev. }[1]=0.56,30-50 \text { per cent. } \\
\left\{\begin{array}{l}\text { dev. }[1]=0.82,30-50 \text { per cent. } \\
\text { het. }[18]=20 \cdot 16,30-50 \text { per cent. }\end{array}\right.\end{array}$ \\
\hline
\end{tabular}

* Several families with suggestively large excess of $R R$.

$\dagger$ Homogeneous slight excess of green seedlings.

small, too small to be manipulable; the plant is strongly inbred, as judged by floral morphology and breeding results. Seeds are set abundantly and shed freely as the plant dries off; they are slightly dormant at harvest and must be either stored for a few weeks or treated with gibberellic acid before sowing. Germination and seedling growth is very rapid.

\section{RESULTS}

The stock studied was little variable in general appearance but comparison of single-plant selfed progenies revealed many minor differences of facies; thus the population is made up of the many homogeneous selfed lines expected of an inbreeder. Only two discontinuously varying characters were detected and both turned out to be under simple genetical control.

* Present address: Scottish Plant Breeding Station, Pentlandfield, Roslin, Midlothian, Scotland. 
The characters were: red $(R) \quad v$. green $(r)$ seedlings and mature plant colours; and black $(B)$ v. brown $(b)$ seeds. Plant colour can be readily scored in the hypocotyls of freshly germinated seedlings in petri dishes. Seed colour refers to testa colour; fruits are shed as such and the fragile pericarps must be rubbed off to reveal the underlying testas. Classification is good except that rare dark brown seeds may be mis-scored as black.

Plants heterozygous at the two loci were detected in a sample of the original population and the two more heterozygotes $(R / r)$ were found in the progeny of glasshouse plants. Green plants $(r r)$ yielded about one per two thousand heterozygous red progeny, so (since reds and greens are about equal) the outcrossing rate is about 0.1 per cent. The table shows that, apart from some slightly aberrant segregation for $R-r$, the breeding results are straightforward.

\title{
3. CONCLUSIONS
}

Cañáhua is an easy and convenient plant to handle but the impossibility of making reliable crosses rules it out as an experimental plant. It would, however, provide excellent material for elementary genetic teaching because it is hardy, responds well to crowding, is reliably selfed and because seedling colours can be easily scored in petri dishes. A bulk stock of $\mathrm{F}_{2} R-r$ seed is available and samples will be sent on request.

\section{REFERENCE}

simmonds, N. w. 1965. The grain chenopods of the tropical American highlands. Econ. Bot., 19, 223-235.

\section{STABILITY OF CHROMOSOMAL POLYMORPHISM IN POPULATIONS OF DROSOPHILA PSEUDOOBSCURA}

\author{
MARVIN DRUGER \\ Deportment of Zoology, Syrocuse University, Syrocuse, New York
}

Received $14 \cdot x \cdot 65$

\section{INTRODUCTION}

Numerous experiments with Drosophila pseudoobscura have demonstrated that metastable equilibria are usually attained when carriers of different third chromosome gene arrangements of similar geographic origin are bred in population cages at $25^{\circ} \mathrm{C}$. (Dobzhansky, 1947a, 1948; Levene, Pavlovsky and Dobzhansky, 1954). When flies come from different geographic regions, equilibria may or may not be attained; monomorphism or stable polymorphism may become established (Dobzhansky and Levene, 1951; Dobzhansky and Pavlovsky, I953; Lewontin, 1958). Equilibria have been attributed to superiority of inversion heterozygotes over corresponding homozygotes.

Most population cage experiments have been terminated soon after an apparent equilibrium has been attained, usually in 12 to 18 months; longterm stability of the polymorphism is debatable in such cages. If, indeed, 